\title{
DURABILITAS CAMPURAN HOT ROLLED SHEET- WEARING COURSE (HRS-WC) AKIBAT RENDAMAN MENERUS DAN BERKALA AIR ROB
}

\author{
Nahyo $^{1}$, Sudarno $^{2}$, dan Bagus Hario Setiadji ${ }^{3}$ \\ ${ }^{1)}$ Mahasiswa Magister Ilmu Lingkungan UNDIP, ${ }^{2)}$ Staf Pengajar Magister Ilmu \\ Lingkungan UNDIP, ${ }^{3)}$ Staf Pengajar Teknik Sipil UNDIP)
}

\begin{abstract}
Tide phenomenon that often occurs in the coastal areas of Indonesia resulted in flooding, which is called the tidal flood. A tidal flood overflow phenomenon of sea water inland. Often some of the roads located in coastal areas are flooded by tidal flood and often causing some damages to the road. Therefore it is necessary to investigate the effect caused by tidal inundation or water bath for asphalt pavement. This research aims to know the durability performance of asphalt concrete mixtures with marinade modification Marshall. The study was conducted with two standard methods of soaking in tidal water and laboratory. Water Immersion method is made by soaking continuous (continuous) and periodic (intermittent). Soaking the specimen in water tidal variation within 6 hours; 12 hours; 24 hours; 48 hours; and 72 hours. While the periodic immersion done by soaking the specimen for 12 hours, then removed during the next 12 hours during 3-days. To view the durability performance of asphalt concrete mixtures used indicator Index of Retained Stability (IRS), Stability Deformation Index, namely First Durability Index (IDP), and the Second Durability Index (IDK).The results showed that continuous immersion damage effects mix quicker on asphalt mixtures than regular immersion. Tidal water used to soak the asphalt mixture Hot Rolled Sheet-Wearing Course (HRS-WC) either continuous or periodic method, has a greater influence than the use of laboratory water. It is shown by the value of the durability of asphalt mixture soaked-tidal water smaller than water-soaked asphalt mixture laboratory standards.
\end{abstract}

Keywords : tidal flood, immersion, durability.

Abstrak: Fenomena air pasang yang sering terjadi di wilayah pesisir Indonesia mengakibatkan banjir, yang disebut banjir rob. Banjir rob merupakan fenomena luapan air laut ke daratan. Seringkali beberapa jalan yang terletak di wilayah pesisir dibanjiri oleh banjir rob dan sering menyebabkan beberapa kerusakan jalan. Oleh karena itu perlu untuk mengetahui pengaruh yang disebabkan oleh genangan pasang surut atau rendaman air untuk perkerasan aspal. Penelitian ini bertujuan untuk mengetahui kinerja durabilitas campuran beton aspal dengan modifikasi keasaman menggunakan pengujian Marshall. Penelitian dilakukan dengan dua metode standar perendaman dalam air rob dan laboratorium. Metode perendaman yang dilakukan yaitu perendaman menerus (continuous) dan berkala (intermittent). Perendaman benda uji dalam air rob dengan variasi waktu 6 jam; 12 jam; 24 jam; 48 jam; dan 72 jam. Sedangkan perendaman berkala dilakukan dengan merendam benda uji selama 12 jam, kemudian diangkat selama 12 jam berikutnya, dan begitu seterusnya selama siklus 3 hari. Untuk melihat kinerja daya tahan campuran aspal beton digunakan indikator Index of Retained Stability (IRS), Stability Deformation Index, yaitu First Durability Index (IDP), dan Second Durability Index (IDK). Hasil penelitian menunjukkan bahwa efek kerusakan perendaman menerus mencampur lebih cepat dari campuran aspal dari perendaman biasa. Air rob yang digunakan untuk merendam campuran aspal Lataston Lapis Aus (HRS-WC) baik menerus maupun berkala, memiliki pengaruh yang lebih besar dibandingkan dengan penggunaan air laboratorium. Hal ini ditunjukkan dengan nilai indeks durabilitas campuran yang direndam air rob lebih kecil jika dibandingkan dengan campuran yang direndam air standar laboratorium

Kata kunci : Banjir pasang, perendaman, duarabilitas. 
Banjir rob yang kerap terjadi di kawasan pesisir pantai Indonesia menyebabkan genangan air di jalan raya. Akibatnya kondisi jalan perkerasan lentur di daerah genangan rob banyak mengalami kerusakan, baik tergolong dalam rusak ringan maupun rusak berat, hal ini disebabkan karena air rob menjadikan daya lekat aspal terhadap agregat menjadi lemah sehingga menyebabkan terjadinya perubahan bentuk atau deformasi pada perkerasan jalan tersebut saat dilewati beban lalu lintas di atasnya. Di samping itu air rob berasal dari laut yang memiliki kandungan tingkat keasaman, kadar klorida $\left(\mathrm{Cl}^{-}\right)$, kadar sulfat $\left(\mathrm{SO}_{4}{ }^{2-}\right)$, dan tingkat alkalinitas yang tinggi sehingga dapat melemahkan kemampuan lekatan aspal dalam mempertahankan ikatan antar agregat baik kohesi maupun adhesi (Prabowo, 2003). Berdasarkan penelitian yang dilakukan oleh Riyadi (2011), diketahui bahwa jalan aspal dapat mengalami kerusakan akibat rendaman banjir rob. Hal ini dibuktikan dengan penurunan nilai nilai, Void Filled with Asphalt (VFA), stabilitas, dan Marshall Quotient (MQ) pada campuran aspal yang telah direndam dengan air yang diambil dari banjir rob. Hasil lain yang didapatkan adalah naiknya nilai void in mix (VIM), void in mineral aggregate (VMA) dan naiknya nilai kelelehan, hal ini membuktikan bahwa campuran aspal mengalami penurunan durabilitas atau keawetan.

Perkerasan jalan di Indonesia umumnya mengalami kerusakan sebelum mencapai umur rencana. Beberapa faktor yang dapat mempengaruhi kerusakan jalan lebih awal (kerusakan dini) antara lain akibat pengaruh beban lalu lintas kendaraan yang berlebihan (over loading), temperatur (cuaca), air, dan konstruksi perkerasan yang kurang memenuhi persyaratan teknis. Salah satu aspek terpenting dalam perencanaan jalan raya adalah upaya melindungi jalan dari air (Suripin, 2004). Nurhuduyah, at al (2009), menyatakan bahwa jenis kerusakan jalan aspal yang di akibatkan oleh genangan air yaitu antara lain berlubang, retak-retak, terlepasnya lapis permukaan (scaling), pelepasan butir (raveling), serta kerusakan tepi perkerasan jalan.

Berangkat dari permasalahan kerusakan jalan aspal akibat rendaman banjir rob tersebut, maka perlu dilakukan penelitian dengan uji laboratorium tentang pengaruh genangan air rob terhadap durabilitas campuran beraspal. Desain campuran yang digunakan dalam penelitian ini adalah desain untuk jenis campuran Lataston Lapis Aus atau dikenal dengan istilah Hot Rolled Sheet-Wearing Course (HRS-WC).

Untuk mendapatkan karakteristik campuran aspal dan pengaruhnya terhadap rendaman air rob, dilakukan pengujian dengan menggunakan alat Marshall. Pada akhirnya akan didapatkan seberapa besar pengaruh air rob terhadap durabilitas campuran beraspal setelah direndam dalam air rob dengan variasi waktu perendaman. Metode perendaman yang dilakukan yaitu perendaman menerus (continuous) dan berkala (intermittent).

Penelitian ini memiliki tujuan untuk mengetahui durabilitas campuran beraspal panas Hot Rolled Sheet-Wearing Course (HRS- 
WC) yang terendam dalam air yang berasal dari air banjir rob dan membandingkannya dengan yang terendam dalam air standar laboratorium. Selain itu penelitian ini juga memiliki tujuan untuk mengetahui sejauh mana pengaruh perendaman menerus (continuous) dan berkala (intermittent) dengan air yang berasal dari air banjir rob dan membandingkannya dengan yang terendam dalam air standar laboratorium terhadap durabilitas campuran beraspal panas Hot Rolled Sheet-Wearing Course (HRS-WC).

Hasil yang diharapkan dari penelitian ini adalah sebagai bahan referensi atau pertimbangan bagi pihak terkait dalam masalah penanganan jalan terutama pada kondisi jalan yang sering terendam oleh banjir rob.

\section{KAJIAN PUSTAKA}

Hot Rolled Sheet (HRS) merupakan jenis perkerasan konstruksi perkerasan lentur (flexible pavement) yang menggunakan aspal sebagai bahan pengikat. Lapisan-lapisan perkerasannya bersifat memikul dan menyebarkan beban lalu lintas ke tanah dasar.

Hot Rolled Sheet (HRS) adalah salah satu campuran aspal dengan agregat seperti halnya campuran aspal beton pada umumnya, namun mempunyai kelebihan khusus yaitu sifat elastisitas yang lebih tinggi dibandingkan dengan campuran aspal lainnya. Dalam campuran aspal beton (AC), kekuatan atau stabilitasnya tergantung pada saling kunci antara susunan agregat (interlocking), namun pada campuran HRS, stabilitasnya tergantung pada kekuatan campuran mortar yang ada,

Volume 1, No. 2, Juli 2015 yaitu merupakan campuran antara agregat sedang/ halus, filler dan aspal. HRS merupakan suatu campuran yang lebih banyak mengandung material halus, dimana akan diperlukan suatu kadar aspal yang lebih tinggi dibandingkan dengan campuran aspal lain (Huriyanto, 2008).

Dalam perencanaan suatu perkerasan dituntut dapat dihasilkan jalan yang baik dan optimal. Jalan yang baik adalah jalan yang mampu menahan atau mendukung gaya-gaya destruktif (kemampuan untuk merusak) dari muatan lalulintas yang diperkirakan akan lewat dan mampu menahan pengaruh durabilitas cuaca serta diharapkan biaya pelaksanaan perkerasan jalan dan pemeliharaannya yang relatif murah. Menurut Departemen Pekerjaan Umum (2005) beberapa sifat campuran yang harus dimiliki oleh campuran beraspal adalah stabilitas (stability) yang tinggi, keawetan/ daya tahan (durability) yang tinggi, kelenturan (flexibility) tinggi, ketahanan terhadap penggelinciran atau geser/ kekesatan (skid resistance), ketahanan terhadap kelelahan (fatique resistance), kemudahan pelaksanaan (workability), impermeabilitas (impermeability).

Beberapa ruas jalan di Indonesia yang terletak di daerah yang berhubungan dengan pantai sering digenangi oleh air rob saat pasang air laut terjadi. Hal ini dapat mempengaruhi kinerja perkerasan aspal khususnya masalah ketahanan atau keawetan jalan (durability). Indikasi awal yang dapat dijadikan sebagai hipotesis bahwa semakin lama perkerasan aspal terendam oleh air, maka sifat durabilitas suatu 
campuran aspal tersebut juga akan berkurang sehingga lambat laun perkerasan jalan akan lebih cepat getas (rapuh).

Salah satu parameter kinerja campuran beton aspal adalah ketahanan (durability). Untuk mendapatkan durabilitas yang baik biasanya dibutuhkan kadar aspal yang tinggi. Walaupun dengan menggunakan kadar aspal yang tinggi tetapi bila jalan tersebut selalu terendam oleh air maka lambat laun jalan akan cepat mengalami kerusakan (getas) sebelum mencapai batas umur rencana.

Salah satu metode yang digunakan dalam mengevaluasi pengaruh air terhadap campuran perkerasan aspal adalah pengujian Perendaman Marshall yang mana stabilitas dari benda uji ditentukan setelah satu hari perendaman di dalam air pada suhu $60 \mathrm{oC}$.

AASHTO (1993) menggambarkan sebuah prosedur yang berdasarkan kepada pengukuran kehilangan dari hasil sebuah kekuatan tekan dari aksi air pada pemadatan campuran aspal. Suatu indeks numerik dari berkurangnya kekuatan tekan diperoleh dengan membandingkan kekuatan tekan benda uji yang telah direndam di dalam air selama 24 jam pada suhu $60 \pm 1$ oC dan 30 menit di dalam air pada suhu $25 \pm 1$ oC di bawah kondisi yang ditentukan.

Spesifikasi Departemen Permukiman dan Prasarana Wilayah untuk mengevaluasi keawetan campuran adalah pengujian Marshall perendaman di dalam air pada suhu $60 \mathrm{oC}$ selama 24 jam. Perbandingan stabilitas yang direndam dengan stabilitas standar, dinyatakan sebagai persen, dan disebut Indeks Stabilitas

Sisa (IRS), dan dihitung sebagai berikut:

$$
I R S=\frac{M S i}{M S S} \times 100 \%
$$

\begin{tabular}{|c|c|c|}
\hline \multicolumn{3}{|c|}{ Keterangan: } \\
\hline IRS & $=$ & Indeks Stabilitas Sisa (\%) \\
\hline MSs & $=$ & Stabilitas Marshall Standar (kg) \\
\hline Msi & $=$ & $\begin{array}{l}\text { Stabilitas Marshall Perendaman } \\
(\mathrm{kg})\end{array}$ \\
\hline
\end{tabular}

Spesifikasi Baru Beton Aspal Campuran Panas mensyaratkan IRS harus lebih besar dari 80 \%. Kriteria Perendaman 24 Jam (satu hari) tidak selalu menggambarkan sifat keawetan campuran setelah masa perendaman yang lebih lama (CRAUS, J. et al, 1981). Peneliti-peneliti ini memeriksa keawetan benda uji dari material aspal yang direndam di dalam air untuk waktu yang lebih lama dan dicari suatu parameter kuantitatif tunggal yang akan memberikan ciri kepada seluruh kurva keawetan. Kriteriakriteria berikut dinilai memenuhi "indeks keawetan" yaitu:

1. Harus rasional dan didefinisikan secara fisik.

2. Harus mengambarkan kekuatan menahan dan nilainya absolut.

3. Harus menunjukkan potensi keawetan untuk suatu rentang yang fleksibel dari masa perendaman.

Harus dengan tepat memberikan gambaran dari perbedaan perubahan waktu perendaman dari kurva keawetan. Dua indeks telah diperoleh yang paling memenuhi kriteria di atas.

\section{a). Indeks Durabilitas pertama}

Indeks pertama didefinisikan sebagai jumlah kelandaian yang berurutan dari kurva keawetan. Berdasarkan Gambar 1, indeks (r) 
dinyatakan seperti pada Persamaan 2:

$$
r=\sum_{i=0}^{n-1} \frac{S_{i}-S_{i+1}}{t_{i+1}-t_{i}}
$$

dengan:

$\mathrm{r} \quad=$ Nilai penurunan kekuatan $(\%)$ pada Indeks Durabilitas Pertama

$\mathrm{S}_{\mathrm{i}} \quad=$ Persen kekuatan yang tersisa pada waktu $t_{i}$

$\mathrm{S}_{\mathrm{i}+1}=$ Persen kekuatan yang tersisa pada waktu $\mathrm{t}_{\mathrm{i}+1}$

$\mathrm{t}_{\mathrm{i}}, \mathrm{t}_{\mathrm{i}+1}=$ Waktu pengkondisian/ perendaman (mulai dari awal proses perendaman), hari

Sebagai contoh, kalau pengukuran diambil setelah $1 / 2,6,12$, dan 24 jam perendaman, maka persamaan 2 tersebut menjadi:

$$
r=\frac{S_{0}-S_{1}}{0,5}+\frac{S_{1}-S_{4}}{5,5}+\frac{S_{4}-S_{7}}{6}+\frac{S_{7}-S_{14}}{12}
$$

Dalam hal ini, Indeks Durabilitas pertama menunjukkan hilangnya persentase kekuatan selama pengkondisian selama satu hari. Nilainilai positif (r) menunjukkan berkurangnya kekuatan, sedangkan nilai negatif menunjukkan bertambahnya kekuatan. Dari Indeks Durabilitas pertama juga memungkinkan untuk menentukan Nilai absolut dari kehilangan kekuatan (R) seperti ditunjukkan pada Persamaan 3:

$$
R \quad \frac{r}{100} \cdot S_{0}
$$

dengan:

$\mathrm{R}=$ Nilai absolut ekuivalen kehilangan kekuatan $(\mathrm{kPa})$ pada Indeks Durabilitas Pertama

$\mathrm{R}=$ Nilai penurunan kekuatan (\%) pada Indeks Durabilitas Pertama

$\mathrm{S}_{0}=$ Nilai absolut dari kekuatan awal $(\mathrm{kPa})$

\section{b) Indeks Durabilitas Kedua}

Indeks durabilitas kedua didefinisikan sebagai rata-rata luasan kehilangan kekuatan yang terbentuk diantara kurva keawetan dengan garis So $=100 \%$. Berdasarkan Gambar 1 . indeks (a) ini dinyatakan seperti pada Persamaan 4:

$=\frac{1}{t_{n}} \sum_{i=1}^{n} a_{1}=\frac{1}{2 t_{n}} \sum_{i=0}^{n-1}\left(S_{i}-S_{i+1}\right) .\left[2 t_{n}-\left(t_{i}+t_{i+1}\right)\right] .$.

dengan:

$\mathrm{a}=$ Nilai penurunan kekuatan $(\%)$ pada Indeks Durabilitas Kedua

$\mathrm{t}_{\mathrm{n}}=$ Waktu pengkondisian/ perendaman ke-n (terakhir)

$\mathrm{S}_{\mathrm{i}} \quad=$ Persen kekuatan yang tersisa pada waktu $t_{i}$

$\mathrm{S}_{\mathrm{i}+1}=$ Persen kekuatan yang tersisa pada waktu $t_{i+1}$

$t_{i}, t_{i+1}=$ Waktu pengkondisian/ perendaman (mulai dari awal proses perendaman), hari

Dimana semua istilah yang didefinisikan pada Persamaan 4 tersirat pada Gambar 1.

Perlu dicatat bahwa wilayah luasan $\mathrm{a}_{\mathrm{i}}$ ditentukan dan terbagi secara horizontal, karena tiap-tiap luasan menunjukkan kontribusi relatif dari kenaikan periode perendaman terhadap total kehilangan kekuatan. Indeks durabilitas/ keawetan kedua juga menunjukkan kehilangan kekuatan yang setara dengan satu hari. Nilai positif dari (a) menunjukkan kehilangan kekuatan, sedangkan nilai negatif menunjukkan peningkatan kekuatan (menurut definisinya a < 100). Karena itu, memungkinkan untuk menyatakan persentase kekuatan sisa dalam satu hari (Sa) seperti pada Persamaan 5 berikut: $S_{a}=100-a$

dengan:

$\mathrm{S}_{\mathrm{a}}=$ Persen kuat tahan yang tersisa dari Indeks Durabilitas Kedua (\%)

$\mathrm{a}=$ Nilai penurunan kekuatan (\%) pada Indeks Durabilitas Kedua 


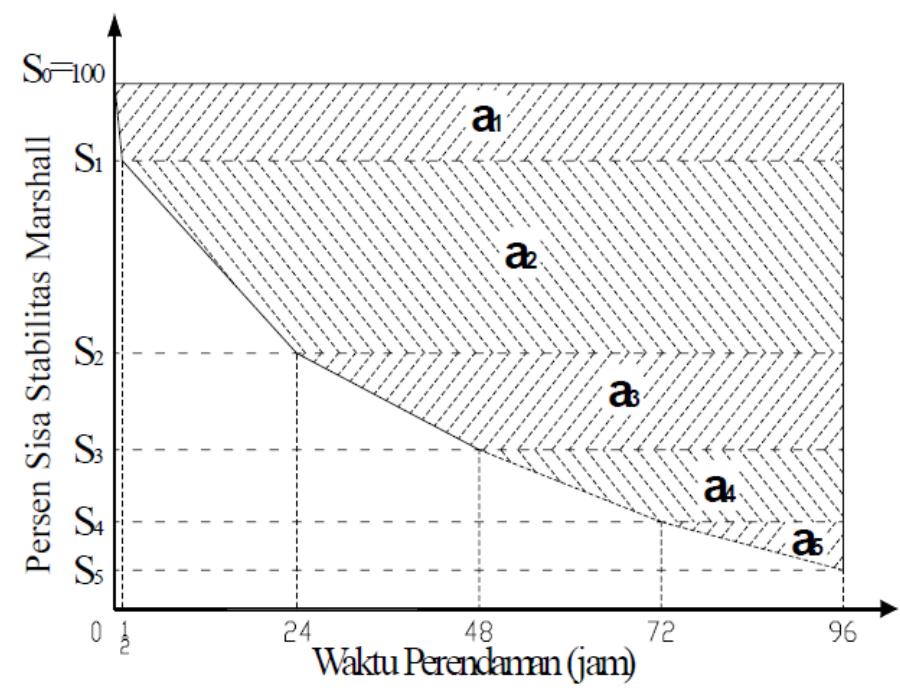

Gambar 1. Gambaran skema kurva keawetan(Crauss at al., 1981)

Indeks Durabilitas kedua juga memungkinkan untuk menentukan Nilai absolut ekuivalen kehilangan kekuatan (A, $\mathrm{kPa}$ ) dan Nilai absolut ekuivalen kuat tahan sisa $\left(\mathrm{S}_{\mathrm{A}}, \mathrm{kPa}\right)$ seperti pada Persamaan 6 dan Persamaan 7 berikut:

$$
\begin{aligned}
& A=\frac{a}{100} \cdot S_{0} \\
& S_{\mathrm{a}}=S_{0}-\mathrm{A}
\end{aligned}
$$

dengan:
$\mathrm{A}=$ Nilai absolut ekuivalen kehilangan kekuatan $(\mathrm{kPa})$ pada Indeks Durabilitas Kedua
$\mathrm{a}=$ Nilai penurunan kekuatan (\%) pada Indeks Durabilitas Kedua
$\mathrm{S}_{0}=$ Nilai absolut dari kekuatan tarik awal( $\mathrm{kPa})$
$\mathrm{S}_{\mathrm{a}}=$ Nilai absolut ekuivalen kuat tahan sisa $(\mathrm{kPa})$ pada Indeks Durabilitas Kedua

\section{METODE PENELITIAN}

Metode penelitian yang digunakan adalah metode eksperimental yang dilaksanakan di laboratorium. Agar tujuan dan sasaran penelitian dapat dicapai sesuai yang diharapkan perlu ditentukan alur/ program kerja penelitian yang akan dilaksanakan. Alur/ program kerja penelitian dapat dilihat pada Gambar 2. Sementara
Metode perendaman yang dilakukan yaitu perendaman menerus (continuous) dan berkala (intermittent). Perendaman menerus dilakukan dengan merendam benda uji dalam air rob dengan variasi waktu 6 jam; 12 jam; 24 jam; 48 jam; dan 72 jam. Sedangkan perendaman berkala dilakukan dengan merendam benda uji selama 12 jam, kemudian diangkat selama 12 jam berikutnya, dan begitu seterusnya selama siklus 3 hari. Penentuan metode dan waktu perendaman ini didasarkan pada pengalaman di lapangan atau lokasi banjir rob dimana banjir rob dapat menggenangi suatu kawasan secara menerus selama berhari-hari karena cuaca buruk atau kondisi lain, dan ada juga yang hanya tergenang pada saat-saat tertentu atau terputus-putus (berkala), misalnya pada tengah malam hingga pagi hari tergenang banjir rob, kemudian pada siang hari telah surut, namun pada malam harinya kembali tergenang air rob. 


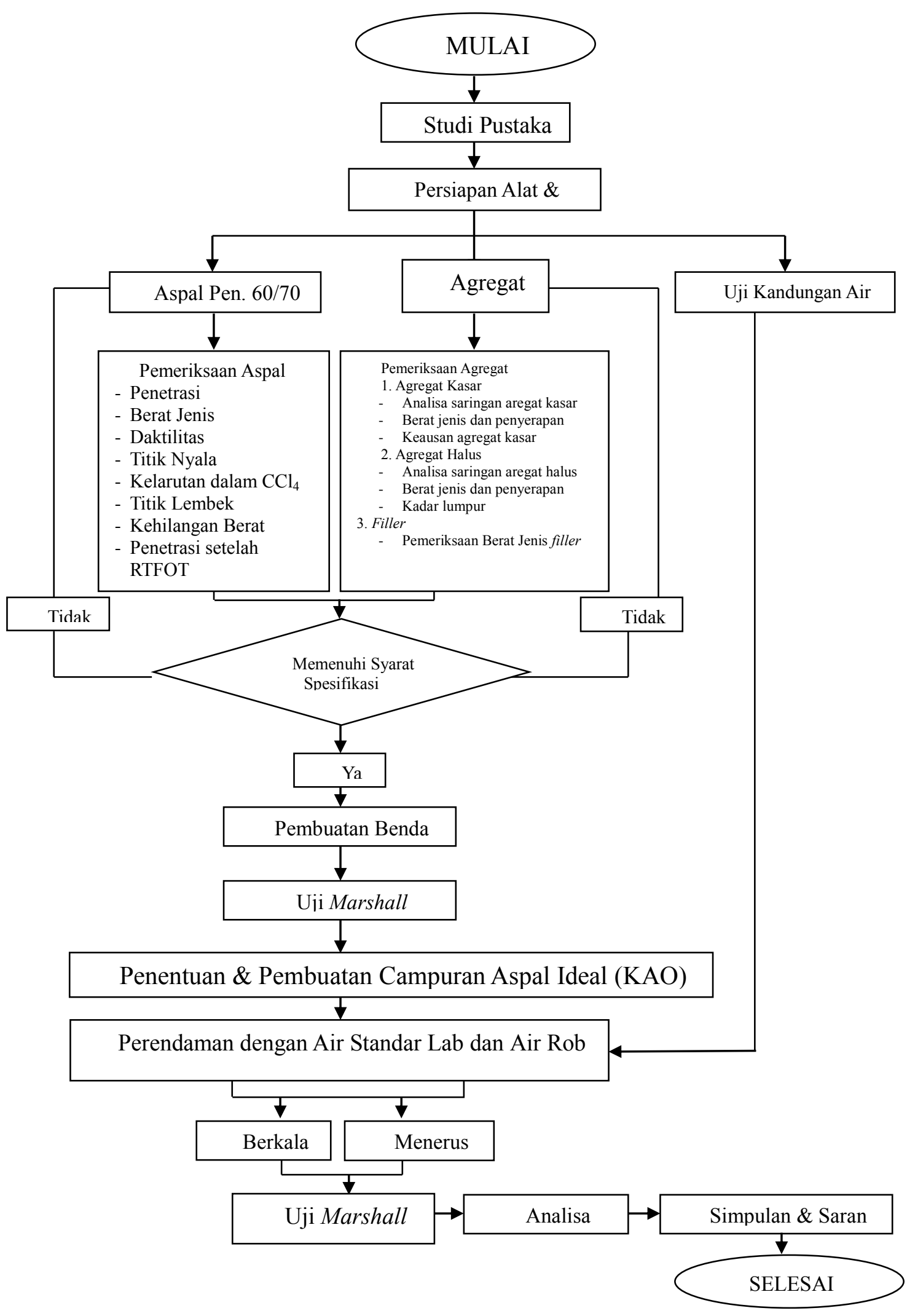

Gambar 2. Bagan Alir Penelitian 


\section{HASIL DAN PEMBAHSAN}

Sesuai dengan bagan alir di atas, dilakukan penelitian pada pengujian material sehingga didapatkan hasil pengujian aspal, agregat (kasar, halus, filler), serta kualitas air laut pasang (rob), dan juga pengujian Marshall sehingga didapatkan nilai parameter Marshall. Hasil penelitian yang diperoleh adalah sebagai berikut:

Tabel 1. Hasil Pemeriksaan Sifat Fisik Aspal Pertamina Penetrasi 60/70

\begin{tabular}{|c|c|c|c|c|c|c|}
\hline \multirow[b]{2}{*}{ No } & \multirow[b]{2}{*}{ Sifat-sifat } & \multirow[b]{2}{*}{ Sat. } & \multicolumn{2}{|c|}{ Spesifikasi } & \multicolumn{2}{|l|}{ Hasil } \\
\hline & & & Min. & $\begin{array}{l}\mathrm{Ma} \\
\mathrm{ks}\end{array}$ & $\begin{array}{l}\text { Pemeriksa } \\
\text { an }\end{array}$ & Metode \\
\hline 1 & Penetrasi $\left(25^{\circ} \mathrm{C}, 100 \mathrm{gr}, 5\right.$ detik $)$ & $0,1 \mathrm{~mm}$ & 60 & 70 & 64,3 & SNI 06-2456-1991 \\
\hline 2 & Titik lembek (ring and ball test) & ${ }^{\circ} \mathrm{C}$ & 48 & - & 51,5 & SNI 06-2434-1991 \\
\hline 3 & Titik nyala (cleveland open cup) & ${ }^{\circ} \mathrm{C}$ & 232 & - & 242 & SNI 06-2433-1991 \\
\hline 4 & Kehilangan berat $\left(163^{\circ} \mathrm{C}\right), 5 \mathrm{jam}$ & $\%$ berat & - & 0.80 & 0,17 & SNI 06-2440-1991 \\
\hline 5 & Kelarutan $\left(\mathrm{CCl}_{4}\right)$ & $\%$ berat & 99.00 & - & 99,17 & ASTM D5546 \\
\hline 6 & Penetrasi setelah Kehilangan Berat & $0,1 \mathrm{~mm}$ & 54 & - & 63,4 & SNI 06-2456-1991 \\
\hline 7 & Daktilitas $\left(25^{\circ} \mathrm{C}, 5 \mathrm{~cm}\right.$ per-menit $)$ & $\mathrm{cm}$ & 100.00 & - & 108,5 & SNI 06-2432-1991 \\
\hline 8 & Berat jenis $\left(25^{\circ} \mathrm{C}\right)$ & $\mathrm{gr} / \mathrm{cm}^{3}$ & 1.00 & - & 1,036 & SNI 06-2441-1991 \\
\hline
\end{tabular}

Tabel 2. Hasil Pemeriksaan Sifat Fisik Agregat Kasar

\begin{tabular}{|c|c|c|c|c|c|c|}
\hline \multirow[b]{2}{*}{ No } & \multirow[b]{2}{*}{ Sifat-sifat } & \multirow[b]{2}{*}{ Sat. } & \multicolumn{2}{|c|}{ Spesifikasi } & \multirow{2}{*}{$\begin{array}{c}\text { Hasil } \\
\text { Pemeriksa } \\
\text { an }\end{array}$} & \multirow[b]{2}{*}{ Metode } \\
\hline & & & Min. & Maks. & & \\
\hline \multicolumn{7}{|c|}{ Agregat Kasar Bp. Max. 3/4" } \\
\hline 1 & Penyerapan air & $\%$ & - & 3.00 & 1,321 & SNI $1969: 2008$ \\
\hline 2 & Berat Jenis bulk & $\mathrm{gr} / \mathrm{cm}^{3}$ & 2.50 & - & 2,606 & SNI $1969: 2008$ \\
\hline 3 & Berat Jenis semu & $\mathrm{gr} / \mathrm{cm}^{3}$ & - & - & 2,698 & SNI $1969: 2008$ \\
\hline 4 & Berat Jenis efektif & $\mathrm{gr} / \mathrm{cm}^{3}$ & - & - & 2,640 & SNI $1969: 2008$ \\
\hline \multicolumn{7}{|c|}{ Agregat Kasar Bp. Max. 1/2" } \\
\hline 5 & Penyerapan air & $\%$ & - & 3.00 & 1,502 & SNI $1969: 2008$ \\
\hline 6 & Berat Jenis bulk & $\mathrm{gr} / \mathrm{cm}^{3}$ & 2.50 & - & 2,627 & SNI $1969: 2008$ \\
\hline 7 & Berat Jenis semu & $\mathrm{gr} / \mathrm{cm}^{3}$ & - & - & 2,735 & SNI $1969: 2008$ \\
\hline 8 & Berat Jenis efektif & $\mathrm{gr} / \mathrm{cm}^{3}$ & - & - & 2,666 & SNI 1969 : 2008 \\
\hline 9 & Tes Abrasi Los Angeles & $\%$ & - & 40.00 & 22,405 & SNI $2417: 2008$ \\
\hline 10 & Partikel Pipih \& Lonjong & $\%$ & - & 10.00 & 6,520 & ASTM D4791 \\
\hline 11 & Kelekatan dengan aspal & $\%$ & 95.00 & - & 98.00 & SNI-06-2439-1991 \\
\hline 12 & $\begin{array}{l}\text { Soundness test atau Kekekalan bentuk } \\
\text { agg. thdp. Magnesium Sulfat }\end{array}$ & $\%$ & - & 12.00 & 3,820 & SNI $3407: 2008$ \\
\hline
\end{tabular}

Tabel 3. Hasil Pemeriksaan Sifat Fisik Agregat Halus

\begin{tabular}{|c|c|c|c|c|c|c|}
\hline \multirow[b]{2}{*}{ No } & \multirow{2}{*}{ Sifat-sifat } & \multirow{2}{*}{ Sat. } & \multicolumn{2}{|c|}{ Spesifikasi } & \multirow{2}{*}{$\begin{array}{c}\text { Hasil } \\
\text { Pemeriksaan }\end{array}$} & \multirow{2}{*}{ Keterangan } \\
\hline & & & Min. & Maks. & & \\
\hline \multicolumn{7}{|c|}{ Agregat Halus (Abu Batu) } \\
\hline 1 & Penyerapan air & $\%$ & - & 3.00 & 1,771 & SNI $1970: 2008$ \\
\hline 2 & Berat Jenis bulk & $\mathrm{gr} / \mathrm{cm}^{3}$ & 2.50 & - & 2,649 & SNI $1970: 2008$ \\
\hline 3 & Berat Jenis semu & $\mathrm{gr} / \mathrm{cm}^{3}$ & - & - & 2,779 & SNI $1970: 2008$ \\
\hline 4 & Berat Jenis efektif & $\mathrm{gr} / \mathrm{cm}^{3}$ & - & - & 2,695 & SNI $1970: 2008$ \\
\hline 5 & Sand equivalent & $\%$ & 50.00 & - & 86,03 & SNI 03-4428-1997 \\
\hline \multicolumn{7}{|c|}{ Agregat Halus (Pasir) } \\
\hline 6 & Penyerapan air & $\%$ & - & 3.00 & 2,051 & SNI $1970: 2008$ \\
\hline 7 & Berat Jenis bulk & $\mathrm{gr} / \mathrm{cm}^{3}$ & 2.50 & - & 2,677 & SNI $1970: 2008$ \\
\hline 8 & Berat Jenis semu & $\mathrm{gr} / \mathrm{cm}^{3}$ & - & - & 2,833 & SNI $1970: 2008$ \\
\hline 9 & Berat Jenis efektif & $\mathrm{gr} / \mathrm{cm}^{3}$ & - & - & 2,732 & SNI $1970: 2008$ \\
\hline 10 & Sand equivalent & $\%$ & 50.00 & - & 86,81 & SNI 03-4428-1997 \\
\hline
\end{tabular}

Tabel 4. Hasil Pemeriksaan Kualitas Air Rob dan Air Standar Lab

\begin{tabular}{clccc}
\hline No. & \multicolumn{1}{c}{ Parameter } & Satuan & Air Rob & Air Standar Lab \\
\hline $\mathbf{1}$ & $\mathrm{pH}$ & - & 8,67 & 7,38 \\
$\mathbf{2}$ & Klorida $\left(\mathrm{Cl}^{-}\right)$ & $\mathrm{mg} / 1$ & $17.800,99$ & 14,99 \\
$\mathbf{3}$ & Sulfat $\left(\mathrm{SO}_{4}{ }^{2-}\right)$ & $\mathrm{mg} / 1$ & $6.206,34$ & 0,17 \\
$\mathbf{4}$ & Alkalinitas $\mathrm{OH}^{-}$ & $\mathrm{mg} / 1$ & 0,00 & 0,00 \\
$\mathbf{5}$ & Alkalinitas $\mathrm{CO}_{3}{ }^{2-}$ & $\mathrm{mg} / 1$ & 137,25 & 0,00 \\
$\mathbf{6}$ & Alkalinitas $\mathrm{HCO}_{3}{ }^{-}$ & $\mathrm{mg} / 1$ & 109,80 & 137,25 \\
\hline
\end{tabular}


Pengujian dari sifat-sifat fisik atau karakteristik baik agregat kasar, agregat medium maupun agregat halus seperti terlihat pada Tabel 1, Tabel 2, dan Tabel 3 menunjukkan bahwa agregat yang digunakan telah memenuhi spesifikasi Bina Marga 2010 sehingga dapat digunakan dalam perencanaan campuran aspal.

Hasil pemeriksaan kualitas air yang diambil dari 2 (dua) lokasi berbeda, yaitu: sampel air Laboratorium Transportasi UNDIP (sebagai pembanding) dan sampel air rob dari tepatnya di Jalan Ronggowarsito Semarang. Dari hasil pemeriksaan kandungan air dapat dilihat bahwa air rob memiliki $\mathrm{pH}$ yang lebih basa dengan kandungan $\mathrm{pH} 8,67$, sementara kandungan $\mathrm{pH}$ air standar laboratorium adalah 7,38. Hasil pemeriksaan kualitas air laut pasang (rob) menunjukkan bahwa konsentrasi kandungan klorida $\left(\mathrm{Cl}^{-}\right)$air rob tinggi yaitu $17.800,99 \mathrm{mg} / \mathrm{l}$. Sangat jauh jika dibandingkan kandungan klorida $\left(\mathrm{Cl}^{-}\right)$air standar lab hanya 14,99 mg/l. Begitu juga dengan kandungan Sulfat $\left(\mathrm{SO}_{4}{ }^{-}\right)$air rob adalah $6.206,34 \mathrm{mg} / \mathrm{l}$, sedangkan air standar lab hanya $0,17 \mathrm{mg} / \mathrm{l}$. Kandungan Alkalinitas $\mathrm{H} \mathrm{CO}_{3}^{-}$air standar lab sebesar $137,25 \mathrm{mg} / \mathrm{l}$ sedikit lebih tinggi jika dibandingkan air rob yaitu 109,80 mg/l.

Dari hasil pemeriksaan kualitas air, terlihat bahwa kualitas air rob dan air laboratorium berbeba. Hal tersebut dikarenakan air rob yang berasal dari percampuran air laut dan air yang berada di sekitar daerah genangan rob memiliki sifat yang hampir sama dengan air laut, hanya saja kualitas perairan di sekitar genangan air rob mempengaruhi air laut yang menggenangi suatu kawasan sehingga terjadi perbedaan kualitas air rob dan air laut. Komposisi kimia air rob dapat dipengaruhi oleh adanya perubahan bahan organik, bahan organik maupun anorganik yang masuk ke dalam air rob akan terlarut di air dan mengalami proses penguraian membentuk larutan padat dan gas. Komposisi kimia di air rob sangat kompleks bahkan saling berinteraksi, sehingga untuk melakukan determinasi bahan kimia dari alam yang terlarut sangat sulit dilakukan (Rompas, at al 2009).

Tabel 5. Pengaruh Perendaman Menerus (Continuous) Terhadap Durabilitas Campuran Aspal

\begin{tabular}{|c|c|c|c|c|c|c|c|}
\hline \multicolumn{8}{|c|}{ Air Laboratorium } \\
\hline \multirow{2}{*}{$\begin{array}{c}\text { Karakteristik } \\
\text { Marshall }\end{array}$} & \multirow{2}{*}{$\begin{array}{l}\text { Spesifik } \\
\text { asi }\end{array}$} & \multicolumn{6}{|c|}{ Lama Perendaman } \\
\hline & & 0 Jam & $6 \mathrm{Jam}$ & $\begin{array}{r}12 \\
\text { Jam }\end{array}$ & $\begin{array}{r}24 \\
\text { Jam }\end{array}$ & $\begin{array}{r}48 \\
\text { Jam }\end{array}$ & $\begin{array}{r}72 \\
\text { Jam } \\
\end{array}$ \\
\hline Stabilitas ( kg ) & $\geq 800$ & 1032,993 & 1003,911 & 981,114 & 952,077 & 933,042 & 898,879 \\
\hline IRS standard (\%) & $\geq 90$ & 100,000 & 97,185 & 94,978 & 92,167 & 90,324 & 87,017 \\
\hline IDP (r, \%) & & 0,000 & 0,469 & 0,837 & 1,071 & 1,148 & 1,286 \\
\hline IDP (R, kg) & & 0,000 & 4,847 & 8,646 & 11,066 & 11,859 & 13,283 \\
\hline IDK (a, \%) & & 0,000 & 1,408 & 3,063 & 5,171 & 6,553 & 9,309 \\
\hline IDK (Sa, \%) & & 100,000 & 98,592 & 96,937 & 94,829 & 93,447 & 90,691 \\
\hline IDK (SA, kg) & & 1032,993 & 1018,452 & 1001,354 & 979,576 & 965,300 & 936,831 \\
\hline
\end{tabular}


Air Rob Jalan Ronggowarsito

\begin{tabular}{|c|c|c|c|c|c|c|c|}
\hline \multirow{2}{*}{$\begin{array}{c}\text { Karakteristik } \\
\text { Marshall }\end{array}$} & \multirow[b]{2}{*}{$\begin{array}{l}\text { Spesifi } \\
\text { kasi }\end{array}$} & \multicolumn{6}{|c|}{ Lama Perendaman } \\
\hline & & 0 Jam & $6 \mathrm{Jam}$ & $\begin{array}{r}12 \\
\text { Jam }\end{array}$ & $\begin{array}{r}24 \\
\text { Jam }\end{array}$ & $\begin{array}{r}48 \\
\text { Jam }\end{array}$ & $\begin{array}{r}72 \\
\text { Jam }\end{array}$ \\
\hline Stabilit: & $\geq 800$ & 1032,993 & 1001,175 & 969,819 & 928,991 & 904,802 & 879,417 \\
\hline IRS standard (\%) & $\geq 90$ & 100,000 & 96,920 & 93,884 & 89,932 & 87,590 & 85,133 \\
\hline $\operatorname{IDP}(\mathbf{r}, \%)$ & & 0,000 & 0,513 & 1,019 & $\begin{array}{l}1,34 \\
9\end{array}$ & 1,446 & 1,549 \\
\hline IDP $(\mathrm{R}, \mathrm{kg})$ & & 0,000 & 5,303 & 10,529 & 13,931 & 14,939 & 15,997 \\
\hline IDK $(a, \%)$ & & 0,000 & 1,540 & 3,817 & $\begin{array}{l}6,78 \\
1\end{array}$ & 8,537 & 10,585 \\
\hline $\begin{array}{l}\text { IDK (Sa, \%) } \\
\text { IDK (SA, kg) }\end{array}$ & & $\begin{array}{r}100,000 \\
1032,993\end{array}$ & $\begin{array}{r}98,460 \\
1017,084\end{array}$ & $\begin{array}{r}96,183 \\
993,567\end{array}$ & $\begin{array}{l}93,219 \\
962,946\end{array}$ & $\begin{array}{l}91,463 \\
944,804\end{array}$ & $\begin{array}{l}89,415 \\
923,650\end{array}$ \\
\hline
\end{tabular}

Tabel 6. Pengaruh Perendaman Berkala (Intermittent) Terhadap Durabilitas Campuran Aspal

\begin{tabular}{|c|c|c|c|c|c|}
\hline \multicolumn{6}{|c|}{ Air Laboratorium } \\
\hline \multirow{2}{*}{$\begin{array}{c}\text { Karakteristik } \\
\text { Marshall }\end{array}$} & \multirow{2}{*}{ Spesifikasi } & \multicolumn{4}{|c|}{ Lama Perendaman } \\
\hline & & 0 Jam & $12 \mathrm{Jam}$ & $24 \mathrm{Jam}$ & 36 Jam \\
\hline Stabilitas ( kg ) & $\geq 800$ & 1032,993 & 999,777 & 980,812 & 955,068 \\
\hline IRS standard (\%) & $\geq 90$ & 100,000 & 96,785 & 94,949 & 92,456 \\
\hline $\operatorname{IDP}(\mathbf{r}, \%)$ & & 0,000 & 0,268 & 0,421 & 0,629 \\
\hline IDP $(\mathbf{R}, \mathrm{kg})$ & & 0,000 & 2,768 & 4,348 & 6,494 \\
\hline IDK $(a, \%)$ & & 0,000 & 1,608 & 2,985 & 5,062 \\
\hline IDK (Sa, \%) & & 100,000 & 98,392 & 97,015 & 94,938 \\
\hline IDK $(\mathrm{SA}, \mathrm{kg})$ & & 1032,993 & 1016,385 & 1002,161 & 980,708 \\
\hline \multicolumn{6}{|c|}{ Air Rob Jalan Ronggowarsito } \\
\hline \multirow{2}{*}{$\begin{array}{c}\text { Karakteristik } \\
\text { Marshall }\end{array}$} & \multirow{2}{*}{ Spesifikasi } & \multicolumn{4}{|c|}{ Lama Perendaman } \\
\hline & & 0 Jam & 12 Jam & 24 Jam & 36 Jam \\
\hline Stabilitas ( kg ) & $\geq 800$ & 1032,993 & 981,016 & 956,392 & 932,422 \\
\hline IRS standard (\%) & $\geq 90$ & 100,000 & 94,968 & 92,585 & 90,264 \\
\hline $\operatorname{IDP}(r, \%)$ & & 0,000 & 0,419 & 0,618 & 0,811 \\
\hline IDP (R, kg) & & 0,000 & 4,331 & 6,383 & 8,381 \\
\hline $\operatorname{IDK}(\mathrm{a}, \%)$ & & 0,000 & 2,516 & 4,304 & 6,237 \\
\hline IDK (Sa, \%) & & 100,000 & 97,484 & 95,696 & 93,763 \\
\hline IDK (SA, kg) & & 1032,993 & 1007,004 & 988,536 & 968,561 \\
\hline
\end{tabular}
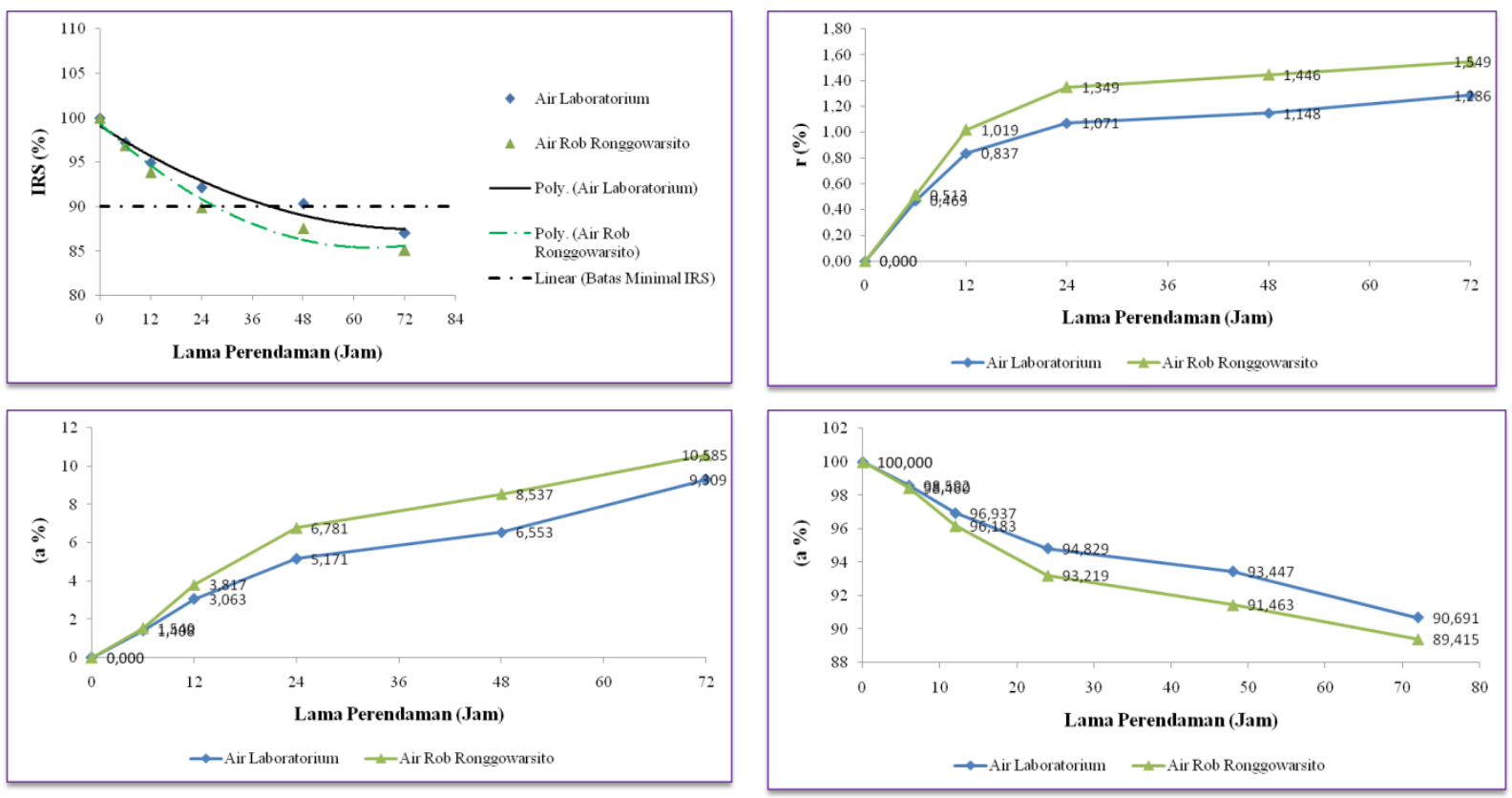

Gambar 3. Hubungan Nilai IRS, IDP, dan IDK dan Waktu Perendaman dengan Pola Menerus 

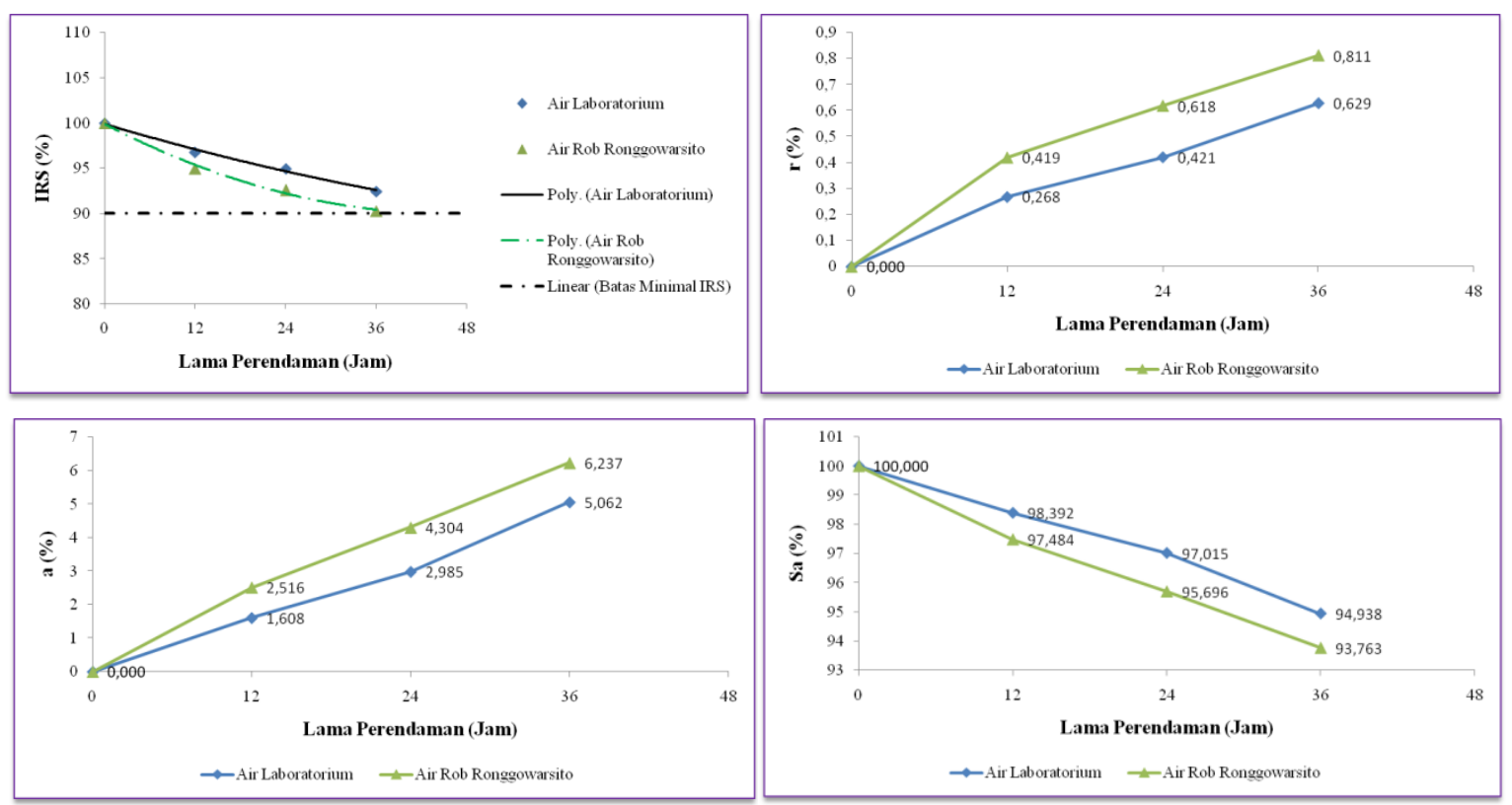

Gambar 4. Hubungan Nilai IRS, IDP, dan IDK dan Waktu Perendaman dengan Pola Berkala

Dari Tabel 5 dan Tabel 6, serta Gambar 3 dan Gambar 5 di atas dapat dilihat bahwa nilai-nilai parameter Marshall setelah mengalami perendaman baik itu menggunakan air standar laboratorium maupun air rob mengalami penurunan pada stabilitas, nilai Indeks Stabilitas Sisa (IRS), dan persen kuat tahan yang tersisa dari Indeks Durabilitas Kedua (Sa). Sementara nilai penurunan kekuatan pada Indeks Durabilitas Pertama (r) dan nilai penurunan kekuatan pada Indeks Durabilitas Kedua (a) mengalami peningkatan. Penurunan dan peningkatan tersebut terjadi pada kedua metode perendaman (menerus dan berkala).

Dari hasil penelitian di atas dapat diketahui bahwa semakin lama campuran aspal terendam air standar dan air rob nilai stabilitasnya cenderung menurun. Penurunan tersebut terjadi pada kedua metode perendaman (menerus dan berkala). Nilai penurunan stabilitas setelah campuran aspal direndam selama tiga hari secara menerus dalam air rob adalah sebesar $14,867 \%$ dari stabilitas awal sebesar $1.032,993 \mathrm{~kg}$. Terdapat perbedaan pada penurunan nilai stabilitas campuran yang direndam air standar lab, yang hanya $12,98 \%$ dari nilai stabilitas awal 1.032,993 kg. Penurunan stabilitas atau kegagalan suatu campuran dapat dikaitkan dengan hilangnya adhesi atau stripping. Kebanyakan material agregat memiliki daya tarik menarik yang lebih besar dengan air daripada dengan aspal. Proses perendaman tersebutlah yang menyebabkan menurunnya nilai stabilitas campuran. Penurunan stabilitas tersebut senada dengan penelitian yang dilakukan Wibowo (2003), Riyadi (2011), dan Fatmawati (2011) yang menyatakan bahwa hubungan antara waktu perendaman 
dengan stabilitas campuran aspal adalah berbanding terbalik, yaitu semakin lama campuran aspal direndam dalam air rob maka stabilitas campuran aspal tersebut akan semakin rendah.

Penurunan nilai stabilitas campuran aspal yang direndam dalam air laboratorium dan air rob tersebut berimbas pada nilai IRS.

Dari hasil penelitian dapat diketahui bahwa pada umur perendaman 24 jam, nilai IRS campuran aspal yang direndam air rob secara menerus telah melampaui batas minimal yang disyaratkan oleh Bina Marga 2010 yang mensyaratkan nilai IRS minimal sebesar 90\%. Sementara pada campuran aspal yang direndam secara menerus dengan air standar laboratorium nilai IRS yang telah melampaui batas minimal yang disyaratkan pada saat umur perendaman 72 jam dengan nilai IRS $87,017 \%$. Hal tersebut sedikit berbeda dengan hasil penelitian Surya Perdana (2012), yang menyatakan bahwa konstruksi lapis perkerasan jenis Laston lapis permukaan (AC-WC) dengan Aspal Polimer Starbit E-55 tidak boleh terendam oleh air laut pasang (rob) selama 5 hari terus menerus. Hal ini dapat diketahui karena pada periode waktu tersebut adalah waktu limit/ kritis dimana nilai kekuatan sisa dibawah $80 \%$ atau tidak memenuhi Persyaratan nilai TSR minimum 80\% (The Asphalt Institute,1996). Perbedaan hasil tersebut dikarenakan jenis lapisan perkerasan yang digunakan berbeda, jenis aspal yang digunakan juga berbeda, dan persyaratan minimum yang digunakan juga berbeda.
Dari hasil penelitian juga diketahui bahwa metode perendaman berkala memberikan pengaruh yang lebih kecil pada campuran aspal dibandingkan metode perendaman menerus. Hal tersebut terbukti dengan masih memenuhinya persyaratan minimal nilai IRS campuran aspal setelah direndam 36 jam (siklus 3 hari) secara berkala. Hal tersebut terjadi pada perendaman dengan air standar laboratorium dan air rob.

Selain Indeks Stabilitas Sisa, Indeks Penurunan Stabilitas juga dapat digunakan untuk mengukur kinerja durabilitas campuran beton aspal. Indeks Penurunan Stabilitas dapat digambarkan oleh Indeks Durabilitas Pertama dan Indeks Durabilitas Kedua. Kondisi durabilitas suatu campuran dapat digambarkan dengan pola pengembangan parameter tunggal setelah melalui serangkaian periode perendaman tertentu. Dalam metode ini tidak ada batasan jumlah dan lama perendaman. Parameter ini dinamakan indeks durabilitas dan terdiri dari dua jenis, yaitu indeks durabilitas pertama dan indeks durabilitas kedua.

Dari Tabel 5 dan Tabel 6, serta Gambar 3 dan Gambar 4, dapat dilihat bahwa pengaruh waktu rendaman pada nilai $r$ dan a untuk masing-masing air rob adalah berbedabeda tetapi memiliki pola atau kecenderungan yang sama, yaitu terjadi persentase penurunan kekuatan campuran terbesar pada periode waktu perendaman antara 0 (nol) sampai dengan 12 jam, kemudian untuk periode waktu perendaman berikutnya hanya terjadi penurunan kekuatan campuran yang relatif 
kecil. Hal itu disebabkan oleh air yang diserap sampel banda uji pada awal-awal waktu perendaman mampu merusak ikatan antara aspal dan agregat sehingga mempengaruhi kekuatan dari campuran aspal tersebut. Sedangkan kenaikan nilai $r$ dan a yang relatif kecil pada periode selanjutnya disebabkan oleh karena pada suhu kamar hanya terjadi sedikit pengurangan stabilitas pada periode lebih lanjut (Syukri, 1999). Hal ini menunjukkan bahwa kehilangan kekuatan terbesar dari campuran perkerasan akan terjadi pada periode awal, dan kemudian akan kehilangan kekuatan lagi pada periode berikutnya sampai terjadi keruntuhan (fail). Kehilangan kekuatan pada periode perendaman setelah periode perendaman pertama relatif kecil. Indeks durabilitas total atau kehilangan kekuatan total umumnya tergantung pada indeks durabilitas atau kehilangan kekuatan selama periode perendaman pertama (Siswosoebrotho at al., 1990).

Persen kekuatan yang tersisa $(\mathrm{Sa})$ pada setiap periode perendaman yang terlihat pada Gambar 3 dan Gambar 4 menunjukkan bahwa air rob lebih mampu menurunkan kekuatan dari campuran aspal. Hal tersebut ditandai dengan kurva keawetan pada campuran aspal yang direndam air rob berada dibawah kurva keawetan campuran aspal yang direndam air laboratorium. Pada saat periode perendaman 3 hari, nilai Sa campuran aspal yang terendam air rob adalah $89,415 \%$ (perendaman menerus) dan 93,763\% (perendaman berkala). Sementara nilai $\mathrm{Sa}$ pada campuran aspal yang direndam air laboratorium relatif lebih kecil. Nilai persen kekuatan sisa campuran aspal setelah terendam tiga hari dengan air standar laboratorium sebesar 90,691\% (perendaman menerus) dan 93,763\% (perendaman berkala).

\section{KESIMPULAN DAN SARAN}

\section{Kesimpulan}

1. Air rob yang digunakan untuk merendam campuran aspal Lataston Lapis Aus atau dikenal dengan istilah Hot Rolled SheetWearing Course (HRS-WC) baik itu metode menerus maupun berkala, memiliki pengaruh yang lebih besar jika dibandingkan penggunaan air laboratorium. Hal ini ditunjukkan dengan nilai indeks durabilitas campuran yang direndam air rob lebih kecil jika dibandingkan dengan indeks durabilitas campuran yang direndam air standar laboratorium.

2. Metode perendaman menerus dapat mengurangi durabilitas campuran aspal yang cepat dibandingkan metode perendaman berkala.

\section{Saran}

Diharapkan agar dicari formula/ rekayasa campuran aspal panas yang lebih tahan terhadap air rob, sehingga didapatkan standar spesifikasi khusus perkerasan lentur di daerah genangan rob. 


\section{DAFTAR PUSTAKA}

AASHTO, 1993. Guide for Design of Pavement Structures. Published by the American Association of State Highway and Transportation Officials, Washington DC.

Bina Marga, 2010. Spesifikasi Umum Bidang Jalan dan Jembatan. Jakarta: Direktorat Bina Teknik.

Craus, J. Et al, 1981. Durability of Bituminous Paving Mixtures as Related to Filler Typa and Properties. Proceedings Association of Asphalt Paving Technologists Technical Sessions. San Diego, California, February 16, 17 and 18, 1981, Volume 50.

Departemen Pekerjaan Umum, 2005.

Panduan Pemeliharaan Jalan.

Jakarta.

Huriyanto, J., 2008. Pengaruh Dust

Proportion Spent Catalyst Rec (Limbah Pertamina) Terhadap Karakteristik Marshall dan Durabilitas pada Campuran Hot Rolled Sheet dengan Kepadatan Mutlak. Tesis. Program Pasca Sarjana Universitas Diponegoro.

Nurhuduyah, N., Dato, A. K., and Parung,

H., 2009. Studi Genangan Air

Terhadap Kerusakan Jalan di Kota

Gorontalo. Simposium XII FSTPT, Universitas Kristen Petra

Surabaya, 14 November 2009.
Prabowo, A. H., 2003. Pengaruh Rendaman Air Laut Pasang (ROB) Terhadap Kinerja Lataston (HRSWC) Berdasarkan Uji Marshall dan Uji Durabilitas Modifikasi. PILAR Vo. 12 Nomor 2, September 2003 : hal. $89-98$.

Riyadi, A., 2011. Pengaruh Air Rob Terhadap Karakteristik Campuran Laston Modifikasi untuk Lapis Permukaan (ACWC-Modified). Skripsi. Universitas Indonesia.

Rompas, R. M., at al, 2009. Oseanografi Kimia. Jakarta: Sekretariat Dewan Kelautan Indonesia.

Siswosoebrotho, B.I., at al., 1990. The Durability of Bituminous Mixtures for Road Pavement Material. Proceeding of the 4th Annual Conference on Road Engineering, Vol. 2, pp 59-73.

Suripin, S., 2004. Sistem Drainase Perkotaan yang Berkelanjutan. Yokyakarta: Andi.

Syukri, 1999. Effect of Salt Water Immersion on The Durability of A Hot Rolled Sheet Mix. Tesis. Program Magister Sistem dan Teknik Jalan Raya (STJR), Institut Teknologi Bandung. 